\title{
The unique Basque peace process: Linking Basque and European generations for global transitional justice
}

OÑATI SOCIO-LEGAL SERIES VOLUME 10, ISSUE 3 (2020), 584-615: PRACTICES OF MEMORIALIZATION AND THE PROCESS OF SOCIAL RECONSTRUCTION

DOI LINK: HTTPS://DOI.ORG/10.35295/OSLS.IISL/0000-0000-0000-1123

RECEIVED 17 SEPTEMBER 2019, ACCEPTED 28 NOVEMBER 2019

\section{JOXERRAMON BENGOETXEA* (iD)}

\section{Abstract}

This paper considers the recent and unique case of transitional justice in the Basque Country. Its uniqueness, from a comparative perspective, lies in its unilateral character. It is mostly because of the pressure of Basque Society, together with the tough stance of the criminal justice system of Spain, that ETA dissolved. The analysis of this process discusses some issues of transitional justice, in tension with formal or traditional justice, and the relevance of this new field in Europe, Spain and the Basque Country. The paper spells out the most significant initiatives in the field of transitional justice adopted in the Basque case, stressing the importance of civil society, and the range of issues arising in a post-conflict situation where different agents have significantly different agendas. The paper concludes by suggesting steps towards an inclusive agenda on memory and narratives of the conflict capable of delivering truth and reconciliation.

\section{Key words}

Transitional justice; Basque peace process; unilateral measures; amnesty; memory politics; truth and reconciliation commissions

\footnotetext{
The research leading to this paper has been done in the framework of the Research Group GI of the University of the Basque Country UPV/EHU IT1190-19 on the EU and Fundamental Rights (Unión Europea y Derechos Fundamentales), of the Spanish Ministry of Education's Research Program DER 201564599-P MINECO/FEDER UE Factores postdelictivos y peligrosidad postdelictual and of ehuGune program of the UPV/EHU. This article draws upon and updates, with significant changes, my article on Transitional Justice $v$ Traditional Justice in the Basque Country, published in JEMEI 2013.

* Ph.D. In Law, University of Edinburgh; Profesor titular of Jurisprudence, University of the Basque Country (UPV/EHU). Director of ehuGune. Coordinator for the UPV/EHU of the Oñati International Master in Sociology of Law and the Ph D Program in Sociology of Law. Contact details: UPV/EHU, Zuzenbide Fakultatea, Manuel de Lardizabal, 2, E-20018 Donostia-San Sebastián. Email address: joxerramon.bengoetxea@ehu.eus Web of Science Researcher ID L-1753-2013
} 


\section{Resumen}

El artículo aborda el reciente proceso de justicia transicional en el País Vasco como un caso único. Su singularidad, desde una perspectiva comparada, reside en su naturaleza unilateral. ETA se ha disuelto sobre todo por la presión de la sociedad civil vasca, junto con la dureza en la aplicación del sistema español de justicia penal. El análisis de este proceso estudia temas propios de la justicia transicional que entran en tensión con la justicia tradicional o formal. Se analiza especialmente la relevancia de este novedoso campo en Europa, en España y en el País Vasco, apuntando las iniciativas más importantes en el campo de la justicia transicional adoptadas en el caso vasco, haciendo hincapié en la contribución de la sociedad civil y reseñando la gama de cuestiones que surgen en un contexto post-conflicto donde distintos agentes tienen agendas significativamente divergentes. En la conclusión se sugieren ideas para trabajar en una agenda convergente e inclusive sobre memoria y relatos del conflicto capaces de aportar verdad y reconciliación.

\section{Palabras clave}

Justicia transicional; proceso de paz vasco; medidas unilaterales; amnistía; política de la memoria; comisiones de la verdad; integración europea 


\section{Table of contents}

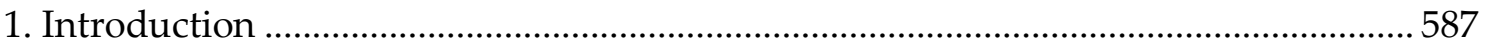

2. Part One: on the Basque Conflict and the Spanish State's Ethos..................................58

3. Part Two. Socio-legal Issues of Transitional Justice ……............................................. 591

4. Part Three. Transitional Justice from the EU to the Basque Country ……...................596

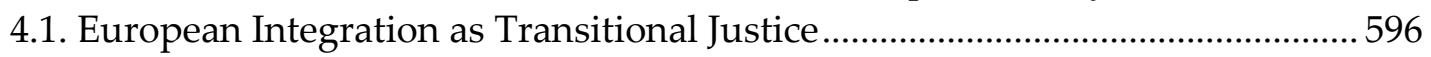

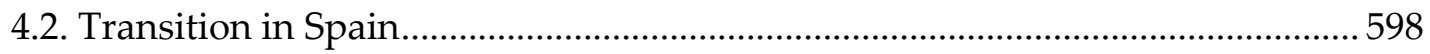

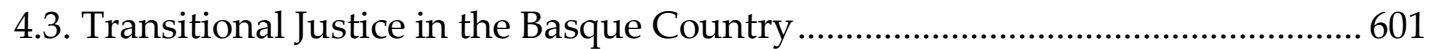

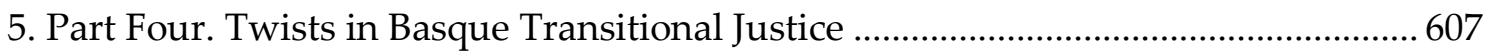

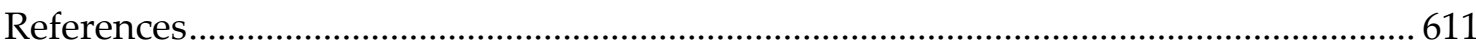

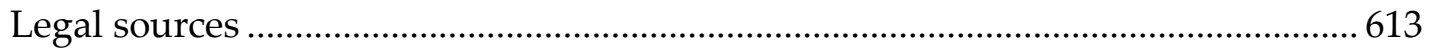

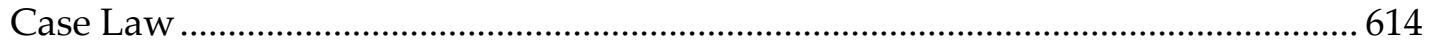

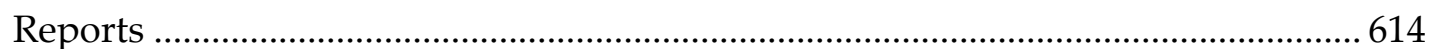


The past has a future we never expect. (Javier Marías, Thus Bad Begins)

\section{Introduction}

Transitional Justice is a field or a toolkit that facilitates the establishment of "justice" and the rule of law in post-conflict societies (The rule of law and transitional justice in conflict and post-conflict societies, Report S/2004/616). ${ }^{1}$ It is also the interdisciplinary understanding and study of that toolkit or field. Transitional Justice (TJ hereafter) is a relevant way of understanding the transformations taking place in the Basque Country in the post-conflict situation created after the final ceasefire declared by ETA on 20 October 2011. From that date to ETA's dissolution almost seven years later, on $4^{\text {th }}$ May 2018, a number of unilateral measures were adopted. However, proponents of the retributive or punitive dimension of the criminal justice system remain critical of transitional, and even restorative, justice. TJ is not official policy in Spain but, interestingly, it is claimed by Basque Civil Society and, to some degree, favoured by the Basque Autonomous Community. ${ }^{2}$

This paper argues that a special case of unilateral $\mathrm{TJ}$ is emerging in the Basque Country, a unique situation where civil society on both sides of the Basque Country, Spanish and French, took the lead in putting pressure on ETA to adopt unilateral steps. Tools and expertise brought from other comparative experiences in the field of TJ had a limited impact only, mostly because the States involved, notably Spain, and to a lesser degree France, ruled out any measure other than the criminal justice system's punitive approach to the fight against terrorism. In spite of this official rejection of TJ, Basque civil society has contributed to finding solutions that enhance and consolidate peaceful living together in order to ensure "justice as fairness", without putting the rule of law in jeopardy. Strictly speaking, the measures adopted by ETA - final ceasefire, decommissioning, apology and dissolution - have not been "unilateral", but rather adopted in "conversation" with, or under pressure from Basque civil society. But they have been adopted in the absence of any negotiation with the State(s) concerned.

Part One will sketch the nature of the so-called "Basque conflict" in Spain. Part Two identifies some key issues in the field of TJ globally. Part Three explores some major experiences and policies developed (or claimed, but not developed) in the political, legal and institutional context: EU, Spain and the Basque Country. Part Four provides a suggestion for a normative TJ agenda for the Basque Country to deal with pending, post ETA, issues.

\footnotetext{
${ }^{1}$ Paragraph 8 provides a nation of transitional justice, as comprising the full range of processes and mechanisms associated with a society's attempts to come to terms with a legacy of large-scale past abuses, in order to ensure accountability, serve justice and achieve reconciliation. These may include both judicial and non-judicial mechanisms, with differing levels of international involvement (or none at all) and individual prosecutions, reparations, truth-seeking, institutional reform, vetting and dismissals, or a combination thereof.

2 Also by the Navarrese Foral Community (2014-2019).
} 


\section{Part One: on the Basque Conflict and the Spanish State's Ethos}

When there have been episodes of conflict and violence affecting the living together of peoples that identify themselves as distinct in a common territory, a key issue is how such conflict will be told and explained. Ownership over the conflict, and all the relevant data related to it, becomes crucial, but also contentious. In the Spanish context, the current political conflict in Catalonia and, to a lesser degree, in the Basque Country, involve competing claims of sovereignty. Claims to sovereignty in Catalonia or in the Basque Country have sparked a reactive ethos on the part of the Spanish state, mobilising the criminal justice system and judicialising politics to the point of inflicting harsh jail sentences on the leaders of the Catalan sovereignty process.

Yet, from the point of view of human suffering, the conflicts differ: the Basque conflict (1968-2011) is one of violence and Human Rights violations, especially terrorism and counter-terrorism, whereas the Catalan conflict, the recent Catalan process (2006-2019) has been peaceful, and generally perceived as such. ${ }^{3}$ The personal victims are those imprisoned, deprived of liberty and of fundamental rights while in preventive imprisonment and also after conviction, as the decisions of the European Court of Justice of 19 and 20 December 2019 have highlighted. This predicament of "victims" of state judicial action may eventually call for a politics of reparation and for restorative justice, even for a special form of transitional justice in the future; but this is not the subject of this article.

In contrast, the Basque conflict has been violent and created unfair suffering and pain on all sides. When ETA was set up during the dictatorship (1958) the memory of the Civil War and of the violent repression of the Franco regime on political opponents was still fresh, only one decade away (1936-1945). Ten years after its creation, ETA murdered its first "targeted" victim, Melitón Manzanas, ${ }^{4}$ head of the "social-political brigades" of the Spanish police in San Sebastian and, formerly, collaborator of the Gestapo. He was both victim of political violence and a perpetrator, for his direct involvement in Human Rights violations and tortures. In 2001, the Spanish Government posthumously awarded him the golden medal on Civil Merit. This paradoxic twist raises the interesting issue of moral and political ambiguity, which is difficult to reflect in the collection of plain data on victims and victimizers where casualties are either one or the other. ${ }^{5}$

\footnotetext{
${ }^{3}$ The reactions to the judgment of the Spanish Supreme Court of 14 October 2019 notwithstanding. The Catalan sovereignty leaders have always advocated and practised civil disobedience. There have been no victims (casualties) in Catalonia other than those persons injured in the context of protests, and material damage has been minimal.

${ }^{4}$ The first victim was Civil Guard Pardines, but the killing had not been planned or targetted; it was the result of gunfire in a road control. Manzanas was the first planned victim. Like the last mortal victim of ETA, Gendarme Nerin in 2010, the first victim, Pardines, had been the result of road controls, thus not planned beforehand, which raises the tactical and strategic issue of the uncontrollable nature of violence. ${ }^{5}$ In his novel Twist, published in 2011, Basque writer Harkaitz Cano deals with a tragic episode of recent Basque history, using the literary techniques of fictional narrative and flashback, memory. The main character and narrator, Diego Lazkano, a sort of anti-hero, was a close friend of "Soto and Zeberio"'s, fictional names for Lasa and Zabala, two young ETA activists who disappeared on 15th October 19831, were tortured during three months and then shot dead by Spanish paramilitary linked to the police. Many years later, the calcined bodies of Soto and Zeberio were found in southern Spain and new evidence was collected. A high official of the Civil Guard, Colonel Rodriguez Galindo was found guilty of torture in
} 
The Basque Country, and Spain as a whole, have gone through a violent history. ETA murdered eight hundred and thirty-seven persons. Thousands of persons were injured $(3,000)$, others were kidnapped, threatened, driven to pay ransom, so-called "revolutionary tax". Many of the victims were police or military but large numbers were civilians, Basque and Spanish. Their relatives and friends also became indirect victims. The fight against ETA by the Spanish State and Security Forces also produced victims of violence and Human Rights breaches (torture, paramilitary groups with ministerial involvement, shooting at demonstrators) and the Criminal Justice System has also produced much pain through official or lawful but over-punitive measures like large prison sentences, serving sentence in faraway prisons, abuse of preventive prison, confinement, not releasing seriously ill prisoners, amongst other measures.

Dating and datifying that conflict is a contentious issue on its own: how far back do you go? Identifying the nature of the actors involved in the conflict is also a delicate task. Transnational discourse and categories of "the fight against terrorism" have permeated the perception. The definition of the different elements or features of the conflict become very problematic: are there good actors and evil actors? Who defines the conflict? Who is a victim? How should prisoners be treated, and in what territory? ${ }^{6}$

Not all facets of the conflict can be analysed here. The key issues in the current, postconflict context are the reparation of victims, the reintegration of combatants and the narratives of the conflict, the politics of memory. In the Basque Country, the "conflict" can be described, politically, as turning around the question of sovereignty, the struggle for self-government and recognition as a "people". Political claims span from the right of the Basque people to create a separate state - claims to independence or secession - to enhanced autonomy and historical rights of self-government, with a middle claim to decide on political status - self-determination or right to decide. The political conflict dates back to the birth of modern Basque nationalism (Sabino Arana), following the Carlist wars of the $19^{\text {th }}$ Century.

The Basque Country and Catalonia achieved autonomous status in Spain toward the end of the II Republic (1936) but a coup d'Etat followed by Civil War and the Franco dictatorship brought an end to this freedom and left a record, leaving aside war casualties, of thousands murdered, summarily executed, disappeared and exiled. Spain has approximately 100000 disappeared persons from this period. The Franco regime was a terror regime for at least a decade (Paul Preston, The Spanish Holocaust). Most disappeared persons were civilians, buried at roadsides, in clearings, mountains and outside cemeteries, or dead while in custody. A recent report on mortal victims during the Civil War and the first years of the dictatorship (1936-1945) established that

these cases and, after serving two thirds of his sentence, was set free in 2013. Soto and Zeberio are tortured and killed by Spanish police but they also engage in the kidnapping and killing of a civil victim as ETA activists. Similar twists are the subject of Cano's recent novel, Fakir's voice (2018) where former ETA activist Arakis defects and is cruelly killed by ETA. Victim and victimizer fuse.

${ }^{6}$ From the ethical point of view, one victim is already one too many. But imagine one were to make a quantitative comparison between victims of terrorist violence, victims of State action, victims of domestic violence, and victims of road accidents. Domestic violence has killed over 1,000 persons since 2003 when it began to be recorded into separate data. According to the official Spanish statistics (INE), in 2017 there were 29,008 women with judicial protection orders. No argument can be drawn from this comparison, only a nuance of datification. 
approximately twenty thousand Basques were killed in that period, and 5,887 of those deaths can be considered crimes against humanity. Most victims were in the Republican camp, but 955 were victims of Republican fire outside combat. 2,252 died in prison, 1,363 in bombings like the Gernika bombings that killed civilians, 895 were summarily executed and 1130 were extra-judicially executed. Countless numbers of prisoners were forced to work as slaves, babies were removed from families and concentration (prison) camps were set up. ${ }^{7}$ The repression was brutal and there was no experience of TJ of any sort in Spain until the Act of historical memory was adopted in 2007, 40 years after transition to democracy (Report of the Special Rapporteur on the promotion of truth, justice, reparation and guarantees of non-recurrence, Pablo de Greiff (A/HRC/30/42)). ${ }^{8}$ Some Autonomous Communities in Spain - Andalusia, Extremadura, Navarre - have adopted their own laws on historical memory and the Basque Country will soon have one. ${ }^{9}$

Different actors in the so-called Basque political conflict relate to different data in order to construct or reflect competing narratives over collective memory and collective identity. Different agendas with diverging periodizations of the conflict draw different conclusions on "memory", categorising victims and victimizers in often opposing ways. Diverse moral conclusions are drawn from the data-based narratives. They look into different historical moments of victimisation and when looking at the same period of violence and conflict, their categories of victims and victimizers are used in contrasting ways, leading to clashing politics of memory. Periodization turns around the question how far back to go in the history of a conflict, and thus, what victims are concerned and what perpetrators are involved.

The largest number of victims and Human Rights breaches took place in the years 1936-1945, everywhere in Spain. Yet, this violent period of Spanish history is not present in the current Spanish agenda on victims of political violence. It is history: the agenda of the past. The "memory of the victims" in Spain normally refers, almost exclusively, to the victims of ETA violence. This is the present, recent or current agenda, and it is highly political. Paradoxically, ETA's final ceasefire in 2011 seems to have had little impact on this agenda. Even its dissolution is ignored in the right wing parties. ${ }^{10}$ The other conflicts, even the other victims in the ETA conflict seem to be second-class victims, because they do not fit into the normative allocation of moral

\footnotetext{
${ }^{7}$ Elaborated by the Basque Government, with the Chair of Human Rights of the University of the Basque Country and the Natural Sciences Institute, Aranzadi.

${ }^{8}$ See the UN Human Rights Council report on truth, justice, reparation and non-repetition (Pablo de Greiff, rapporteur, 2014). The report concludes that Spain has failed to put in place a politics of memory and truth, and victims of this period consider themselves as second-class victims.

${ }^{9}$ There is a popular legislative initiative tabled on 3 July 2019 and on 24 October 2019 the Basque President tabled before the Government a draft bill to submit to the Basque Parliament on the subject.

${ }^{10}$ As an example, the Spanish Popular Party in 2019 has identified ETA and Catalonia as its major political issues for the coming years 2019-2023. Some victims' associations replied that this party seems to want ETA back and uses victims' pain for political ends (Aduriz 2019a, 2019b). The most flagrant example of this calculated denial of ETA's finale is the opening of the 11/13 trial in the Audiencia Nacional against 47 civilians, mostly lawyers, accused of being members of ETA and setting up the prisons front, aimed at representing ETA prisoners as a block within the Spanish penitentiary system. On 16-09-2019 a guilty plea was agreed with prosecution and only two of the accused are to serve short-term sentences.
} 
virtues and blameworthiness, prevailing in large sectors of the Spanish criminal justice system and political culture.

\section{Part Two. Socio-legal Issues of Transitional Justice}

Transitional Justice (TJ) is often understood as a field or a toolkit that facilitates the establishment of "justice" and the rule of law in post-conflict societies. The specific goals are to bring about the right to "truth", access to "justice", victims' right to "reparation", to recognition of their suffering and to have their dignity restored, but the goals are also social reconciliation and non-repetition of violations. Besides focusing on the fair distribution of basic goods and on procedural-discursive views, the term "justice" also refers to the administration of justice in an institutional system of courts, or through alternatives to litigation and to the criminal justice system. Criminal law - the criminal justice system - takes an institutional and attributive approach to guilt, and stresses the role of institutional society - the legislator - in deciding universally on the allocation of responsibilities, reparation and compensation, even on restoration. It also analyses the role of the courts in instantiating such allocation in the particular cases regarding victims and perpetrators. Traditional insistence on the particular criminal act and on the mens rea of the perpetrator now face challenges from a greater focus on the "actor" or perpetrator, often stigmatized as the "enemy", the "terrorist", or as "dangerous" and also from "victim"-oriented approaches.

Within the law, it is also useful to distinguish instruments and institutions usually grouped under soft law - e.g. recommendations, policy documents, procedures of dispute resolution like mediation or conciliation, truth commissions, international support groups - and hard law - legislative instruments, judgments, courts, enforcement agencies, prisons, the criminal laws and criminal procedure, namely the criminal justice system. There also are different levels of governance especially in the composite decentralised - e.g. the Basque Autonomous Community, or Navarre in Spain - or federal systems, each level with its own powers and competences. Whereas soft law measures can be adopted by different institutions simultaneously, hard law measures recognising rights and imposing obligations enforceable in law, typifying crimes, arranging institutions, can only be adopted by the competent legislator for any given jurisdiction. They will have to be structured according to relevant principles like subsidiarity, proportionality and coordination, as in the EU and Council of Europe context.

The issue of competences and powers - who does what, who can legislate in what areas - becomes crucial when analysing the legal approaches, and is conveniently related to the study of governance. Restoring the rule of law and the criminal justice system of a society, a primary aim of TJ, is normally the exclusive competence of the state legislator, who holds powers in criminal justice. But governance in the polity is not only to be understood from an institutional, constitutional, vertical perspective covering the hierarchical institutions, lower levels of government, the central powers and the federal or decentralised levels, the separation of powers in the trias politica. Governance is also about civil society, community, citizens' initiatives, NGOs, research and educational organisations and public private partnerships. And the role of civil society in TJ is paramount. Therefore TJ can deploy through both hard and soft law 
measures, depending on the competences but also on the policy choice, bottom up initiatives and democratic decisions.

"Justice in a context of transition after conflict" and "justice to facilitate transition" are two understandings of $\mathrm{TJ}$ as coming to terms, in the first case, with past crimes, even with atrocities and, in the second case, as a means to bring an end to violence, widescale conflict and human rights abuses. TJ operates in a post-conflict context but it can also assist conflict-ridden societies and its immediate priority might be to bring about an end to conflict, cessation of hostilities, rather than addressing its consequences, an issue to tackle later, in post-conflict situations. Transition implies regime change, from dictatorial, totalitarian regimes to some form of constitutional democracy. But transition can also consist in specific settlements to bring about ceasefire. Peaceful or smooth transitions are often opposed to transitions characterised by catharsis, violence or prosecutions. The TJ toolkit provides policy options or a set of approaches and solutions broadening the traditional focus on criminal prosecutions against perpetrators. TJ balances fair treatment of perpetrators with their due desert but enlarges the focus to capture larger societal and institutional responses to wide-scale abuses taking primarily into account the suffering of all types of victims but also the needs of communities. These needs span from general and individual prevention - i.e. non repetition - through reparation and restoration, to reconciliation.

Rather than a normative structure, TJ is better seen as a normative process that faces up to the past (Bell 2009). Neglecting, discarding or tiptoeing over a totalitarian and violent past in a given society amounts to a rejection of justice. TJ reports, faces up to and makes critical sense of past scenarios of violence, pre-transition stages characterised by war or armed conflict, totalitarian regimes and/or and human rights violations. It aims to collectively construct a vision for the post-transition horizon of an, ideally, reconciled society. In the new horizon the conflict is transformed, if not resolved, and peaceful living together becomes a shared ideal. Furthermore, in such horizon human rights violations are universally despised, condemned and avoided by all actors in society. If that ideal is attained, TJ will have succeeded and will step back, giving way to justice, ideally restorative justice, or justice tout court.

The transition phase is a bridge, a process, between the two horizons. In the transition phase categories projected from the past like victims or victimizers - perpetrators - are still operating and largely shape the form of transition where each of these actors brings in their own perceptions, experiences, expectations, claims, and memories. However a view of the post-transition future is one where such strong experiences of the past are turned into a collective, inter-subjective, "memory", but no longer determine the normative agenda. Ideally, in the new horizon those categories - victims, victimizers - are seen as historical categories of a conflict that has been overcome. Transitional virtues like forgiveness, reconciliation, pardon, assumption of guilt and responsibility, practices like shaming and blaming, confronting through discourse, avoiding revenge, are all instrumental during transition; they facilitate but are not carried into post-transition. In post transition, only the narratives about the past - pretransition and transition stages - are in play in a politics of memory. They need not be all shared, nor shared by all, but all actors should be living together and sharing the public space. 
Time and dynamic perspective are of the essence in TJ. To conceive a theory of justice along transitional lines means to replace the traditional "static", "fixed" approaches to justice as those advanced by contract-theories with more dynamic and contextuallyoriented judgment approaches (Corradetti 2013). There are three key moments: facing up to the past, facilitating transition and narrating the past. The first moment and requirement of transition is to decide to face up to the past, ruling out amnesty and amnesia unless amnesty is itself the end result of a collective societal process that has examined the past and decided to forgive or forgo criminal sanctions. Amnesty is already a problem, but amnesty plus amnesia can be a direct affront to victims. Healing and reconciliation seem impossible then.

The second moment is transitional itself, but transition to peace and civil society, overcoming enemy status and recognising each other as relevant others. Some form of moral progress obtains when sensitivity is gained and recognition is directed towards individuals, communities and situations previously ignored and deprived of due recognition (Honneth 2004, 354). The Basque case fits the framework of TJ by raising the awareness of the importance of extending recognition of the others, those who had been excluded from view in the discussion of political debates and in the shared discussions of the future; and this includes victims on all sides of the conflict, but also political options that had been declared illegal, and last, not least, those who were invisible, women, immigrants, excluded persons. The transition period becomes crucial because it concentrates the multiple twists in TJ: from past to future (Teitel 2000, p. 11 and passim), from revenge to forgiveness (Minow 1998), from presence to disappearance, from insistence to avoidance, from living in the past to amnesia, from victim to perpetrator, from impunity to over-punity, from criminal trial to betrayal of the trial, from desert to amnesty, from realpolitik to utopia (Koskenniemi 2005), from the paramountcy of the claims to end the conflict - peace as ceasefire - to new goals regarding gender justice, the rights of children, of minorities, the end of corruption, land and asset restitution and redistribution, or even addressing social exclusion related to the conflict, for instance through better provision of economic, social and cultural rights. There is a tension between a desire for calm after war, for turning the page, and the importance of putting human rights violators on trial. There is a tension between the need, as part of a political transition, to create a reliable historical record of past abuses and the coherence of forgiveness in politics. There is a further tension between collective involvement and orchestration of human rights violations and the individual allocation of responsibility of the criminal justice system, deeply ingrained in most legal cultures. Ultimately, there is tension between $\mathrm{TJ}$ and the traditional justice of the criminal justice system (Eisikovits 2014).

These tensions point to a problem at the heart of international criminal law and are reflected in the following challenge: Does the unique nature of mass atrocity, wherein numerous people harm others with differing degrees of acquiescence and direction from a large bureaucratic class, really lend itself to the legalistic commitment to individualize guilt on the basis of direct evidence? Or do the distinct features of such crimes require relaxing our standards of individual responsibility so as to implicate the 
relevant part of the state structure that made the atrocities possible? ${ }^{11}$ If the latter, it may be difficult to hold fast to the justification of such trials as expressing a firm commitment to legalism and the idea of the rule of law so dear to most legal cultures.

Amongst the major instruments in the transitional justice ${ }^{12}$ toolbox two are prominent: permanent or ad hoc Tribunals to try atrocities and establish guilt and criminal responsibility, and Truth (and Reconciliation) Commissions following the model of the South African Truth and Reconciliation Commission, itself based on previous Latin American experience. ${ }^{13}$ There are other instruments like vetting the democratic nature of institutions and procedures, verification commissions, ${ }^{14}$ laws on memory, on victims, on the recognition of past events (genocide, war atrocities...), even laws of amnesty in certain cases.

The major criticisms of international tribunals are that they impose victors' justice, that they impose penalties retroactively and against the nullum crimen, nulla poena sine lege principle of legality (also the natural law v positive law), and that they are selective in the choice of indictments, since courts find it easier to prosecute lower level officials and military personnel, often leaving untouched the more senior figures who devised the violent policies (who have command responsibility but do not have actual "blood on their hands"); and related to this, there is the risk of over-punishing the latter while leaving the commanders under impunity. ${ }^{15}$

As regards Truth Commissions, they also deal with the past, investigating continued patterns of abuses and not specific, isolated, cases. They operate for some fixed period of time and submit reports summarizing their findings; they are usually official bodies sanctioned by the state; they normally have as their goals to unearth, clarify and

\footnotetext{
${ }_{11}$ An application of this dilemma to the Basque context would lead to consider responsibility of the state apparatus behind the paramilitary, or the practice of torture by State agents. It is also reflected in a topos that carries some weight in part of the Spanish criminal justice system according to which all social movements around the Basque nationalist left are "part of ETA" (¡todo es ETA!). Here, individual involvement, mens rea and concrete criminal acts twist to a collective construction of criminality where sympathy with "the cause" is criminal. But when it comes to the state as a whole, it cannot be involved in "state crime" since only individual officers can be legally responsible. Double standards are at play.

${ }^{12}$ The 1998 Statute of the ICC (article 75) established that the Court must create instruments for reparations such as restitution, indemnities or rehabilitation, and the 2005 UN Basic principles and guidelines listed the following restorative mechanisms: restitution, compensation, rehabilitation, satisfaction and guarantees of non-repetition. With these guidelines, the UN moved towards sanctioning functions beyond restorative justice for reparations: satisfaction (for victims) includes verification of truth, an official declaration or judicial decision restoring the dignity of victims, public apologies, commemoration and tributes to victims. See Closa 2011, p. 26.

${ }^{13}$ Nunca Más in Argentina, or Chile where the truth commission's work provided evidence to support the Spanish extradition request that eventually led to Pinochet's arrest in Britain, and the report From Madness to Hope in El Salvador, instrumental in shaming and eventually removing from service some of the military officials accused of especially egregious abuses.

${ }^{14}$ No serious proposal has been made to set up any International Tribunal for the Basque Country. A Group of International Experts, chaired by Ram Mannikalingam, of the Amsterdam based Dialogue Advisory Group, was created to encourage and facilitate dialogue and a negotiated end of violence. This group was also active in verifying the credibility of ETA's final ceasefire as an International Verification Commission. Interestingly it was commissioned by relevant NGOs of Basque civil society, with some communication pathways to the Basque Institutions, and accepted by ETA as facilitator.

15 This is the subject of Camilo Umana's (2017) doctoral thesis as regards Colombia, University of the Basque Country and University of Ottawa.
} 
formally acknowledge past abuses, responding to the needs of victims, helping create a culture of accountability, outlining institutional responsibility and possible reforms, advancing the prospects of reconciliation and reducing conflict over the past (Hayner 2000 , p. 24). ${ }^{16}$

While Truth Commissions have fewer coercive powers than courts - because, amongst other things, they cannot compel governments to carry out their recommendations and have no authority to punish - their mandate for investigating the broader pattern of abuses, and their tendency to put the victims at the centre of their proceedings give them moral credibility and legitimacy. Also, they may tackle some of the problems of individual responsibility of the criminal justice system, allowing for findings of collective responsibility. But this is not always secured. In the case of South Africa, a major problem was that those responsible for heinous crimes were given freedom in exchange for a "bit" of truth telling, while victims and their families were generally denied access to the courts. Truth prevailed over justice, understood in a procedural sense as prosecution in the courts, imputation and prison sentences.

Another relevant feature of Truth Commissions or similar mechanisms is that they can facilitate enquiry into the why of conflicts and systematic human rights violations, the policies that brought them about and the effects of those policies on the actors and sectors in Society to an extent that is not possible in (traditional) criminal justice focused on individuation of responsibility, on the what, or if at all, the how. There is the further problem of constitutional competence to set up "official" commissions: which institution has the power to take initiatives that may be seen as conflicting with the administration of justice, even when the courts have ruled out any fact-finding on the events concerned. ${ }^{17}$

But what about the third moment, memory. Is historical memory a necessary corollary of Truth? Is there a risk that truth, as quasi-officially established by the Commission, might fade away from a community's ethos? Is it futile to impose a duty to memory?

\footnotetext{
${ }^{16}$ Hayner participated in a seminar on proposals of Transitional Justice for the Basque Case organised in Donostia-San Sebastian on 17 October 2013 to commemorate the second anniversary of the Aiete Declaration. I happened to moderate the expert panel she and Pierre Hazan shared, and have drawn important clues from both experts and from the entire seminar for this contribution. The most salient voice calling for some sort of TC for the Basque Country is Jean Pierre Massias, an outstanding academic and practitioner of Transitional Justice involved with Fondation Varenne. A variant of TCs that has gained ground in the Basque case are the number of reports about past abuses and crimes that have been commissioned by Basque and Spanish institutions (and by the Memorial Centre and Gogora), as mentioned throughout this paper.

17 On 28 November 2008, the Basque Parliament passed a non-legislative proposal to denounce an "eventual obstaculización" by the Head of the State Prosecution in the action brought before the Audiencia Nacional and urging the Spanish and Basque governments to set up Truth Commissions, together with families, disappeared, executed and expelled victims' associations and with legal agents and established academics at the local, state and international level, so as to set up a process based on truth, justice and reparation of those who were repressed by Francoism. The Basque Government followed suit and drafted a document, Bases para la puesta en marcha de una Comisión de la Verdad en Euskadi; see Landa 2009. On 8 February 2018, EH-Bildu put forward a Bill on the Historic Memory Law to acknowledge and repair victims of Franquismo" between 1936 and 1978. See Part One.
} 
Perhaps we should also contextualise an obsession with "memory" and the narratives of the violent past from a historical perspective. ${ }^{18}$ More on this at the end of Part Three.

\section{Part Three. Transitional Justice from the EU to the Basque Country}

This section reconstructs the institutional framework of the policies on Transitional Justice in a multilevel European setting, from the supranational EU institutions to the local level in Basque towns. The examination will not be exhaustive but rather indicative or illustrative of the issues addressed at the EU level, at the Spanish state level, at the Basque national level, and at the federal and local level within the Basque Country.

\subsection{European Integration as Transitional Justice}

The very concept of European integration, from the Schuman declaration to the latest accession - Croatia, July 2013 - is about securing peace and living together by establishing concrete bonds of solidarity, and thus, arguably, about TJ. War atrocities were perpetrated by all belligerents, genocide by totalitarian regimes, societies devastated by World War II, and civil wars in many of the Member States. European integration was the road to free markets, but also to democratic societies, rule of law and human rights. European integration, the three Communities and the Council of Europe, were also designed in a background characterised by Cold War, a fragile peace, and by the urgent reconstruction needs of post-war societies to ensure economic development and welfare. In the aftermath of World War II, forgetting, not remembrance, was considered the better approach towards the past (i.e. Adenauer's politics, Vichy "myths" in France, neglect of Holocaust memory in all European countries etc.). European integration was to be forward looking, future oriented. The past - European civil wars, strategies of domination, colonialism, genocide and exploitation - was for each European society to beckon.

An analysis of any possible TJ policy of the EU would distinguish external relations external action - from domestic or European instances of TJ. The EU has got involved in TJ throughout the world indirectly, as part of its external policy - Common Foreign and Security Policy - and through its support for International Tribunals and the International Criminal Court.

As regards the internal European dimension there is arguably no TJ policy as such, in the sense described in Part Two, but EU's involvement in conflict-ridden regions of the (Member States of the) EU has traits that relate with the TJ toolkit. The PEACE III program for Northern Ireland (EUR 11.2 million) is worth mentioning in this regard. This has been possible because of the many peace initiatives internal to the region, but also because there has been an active involvement of the two Member States concerned, the UK and Ireland, thereby recognising a significant 'European' dimension

\footnotetext{
18 Philippe Texier, 14 May 2018, speaking for the association of jurists for peace in the Basque Country: “La mise en place d'une Commission de la vérité, comme il en a existé à l'issue de la plupart des conflits armés, est nécessaire, sous une forme à déterminer. Sans doute la société civile, qui a fait preuve, au long de ces années, de beaucoup d'imagination et d'une volonté sans faille de lutter pour la paix, peut-elle y pourvoir, mais il serait peut-être temps que les Etats français et espagnol prennent enfin en compte la situation actuelle et s'engagent résolument dans le processus de paix “.
} 
to the resolution or transformation of the conflict, which ceases to be an internal question to the UK, or to Ireland. ${ }^{19}$ This is a key difference with the Basque case, for neither Spain nor France recognise there is any conflict to begin with. To the extent that the EU itself might consider that there could be any issue of TJ in the Basque Country, this would be considered "purely internal" to Spain. This is exactly the same as the EU response to the Catalan process. As a consequence, the EU does not consider itself allowed to mediate or intervene in any way or to favour any particular instrument of TJ.

A politics of memory is gradually taking place in different parts of the EU, and some support from institutions like the European Parliament helps consolidate these forms. This discourse on memory has been channelled mainly around two constitutional moments: the construction of European integration post-WWII and the enlargement to the East of 2004 (also 2007); but it could also apply to the Greek, Spanish and Portuguese post-transitions and accessions. The most recent accession of Croatia (2013) may also open up a discourse on memory in the former Yugoslavia. What is most interesting is how the prospect of joining the EU itself becomes a lever to transition and to internal reconciliation in such countries. According to Carlos Closa (2011, p. 5), "claims on memory in the EU are claims for recognition and, because of this, the way in which they are addressed contributes to the construction of an EU-specific model of identity at the level of specific nations within the EU and at the level of European (EU) identity".

The most far reaching inward looking European level measure of transitional justice was the Framework Decision on Denial of Holocaust (FDDH), a salient piece of legislation, having its origins in measures to combat racism, xenophobia and antiSemitism. It imposed an obligation to criminalize denial of the Holocaust. Although the decision fails to address specific practical needs like the transnational dimension of the crimes and although the crime of denial operates completely within the national retributive sphere of justice, preserving the plurality of national models, some of which grant special weight to free speech, the FDDH does provide a symbolic and expressionist rationale.

More important for TJ in Europe is the work carried out by the Council of Europe with the system of the European Convention of Human Rights and its Strasburg Court, but also the Human Rights Committee. ${ }^{20}$ Other key players on TJ are the Venice Commission on Democracy through Law and the system of the Organisation for Security and Cooperation in Europe, the follow up to the Helsinki Final Act of the Conference. ${ }^{21}$ It is revealing that the EU Agency for Fundamental Rights should not have any specific activity related to TJ. Whereas Europe - the EU and the Council of Europe - provide a minimal control of TJ measures on the basis of Human Rights, it

\footnotetext{
19 The prospect of Brexit taking place on 31 $1^{\text {st }}$ January 2020 could pose an existential threat to the Good Friday Agreement, since the EU was a major component of that transitional justice scheme.

${ }^{20}$ See on this point Patrick Macklem (2005), who compares the Brok case before the HRC with the Malik v Poland case before the ECHR.

21 According to its website (www.osce.org), the OSCE offers a forum for political negotiations and decision-making in the fields of early warning, conflict prevention, crisis management and post-conflict rehabilitation, and puts the political will of its participating States into practice through its unique network of field missions. TJ is dealt with under the heading Conflict Prevention and Resolution.
} 
can be said that it has not developed all its potential, and it defers and shows comity to the constitutional and legislative choices made at the Member State level.

\subsection{Transition in Spain}

Spain lived its own transition to democracy from dictatorship, but insofar as it did not face up to the past, it did not really undergo a Transitional Justice in the sense discussed in Part Two. Rather, in order to democratise, it aimed at transformative constitutionalism (Klare 1998, p. 146), expecting the entry into force and implementation of its 1978 Constitution to transform the entire social system, and not only the legal and political systems, without removing a single official from the dictatorship. Spain combined amnesty and amnesia through a sort of "pact of forgetting", pacto de olvido. ${ }^{22}$ As novelist Javier Marías put it in Thus Bad Begins, "everyone accepted this condition, not just because it was the only way the transition from one system to another could proceed more or less peacefully, but also because those who had suffered most had no alternative and were in no position to make demands (...). The promise of living in a normal country was far more alluring than the old quest for an apology or the desire for reparation". This was particularly clear in the thirty-year period spanning from the Amnesty Act of 1977 to the Law of Historical Memory Act of 2007, and perhaps to this day. The need to preserve "peace and order" and to ensure a certain version of "la Transición" prevailed ${ }^{23}$. Human Rights violations were committed by combatants, in both sides, during the Civil War and then by the Franco regime. ETA and anti-Franco armed groups, later tagged as terrorist groups, also engaged in Human Rights violations, initially targeting State police and later generalising their attacks indiscriminately on politicians and civilians. ETA has been active between 1968 and 2011. But only post-amnesty violations (post 1977) have been addressed by the law and by official policy. The past was brushed aside. Pardon or amnesty has been interpreted as clearing any agent of the state involved in State or paramilitary abuses. Perpetrators were and are protected both from criminal charges and from civil liability, which amounts to a complete denial of justice in transition. Official records of past events have, in many cases, been destroyed, or "expurged".

Forgetfulness, of course, is a non-solution:

[F]orgetting cannot serve as the basis for peace-making. It is destructive on both the individual and collective levels. It compounds the suffering of individuals by forcing them to watch their tormentors walk around freely, re-enter politics, or maintain their posts in public service and the military. All of this takes place while their own painful memories and traumas remain unacknowledged. Furthermore, policies advocating forgetfulness decrease the chances that victims will be compensated for their suffering. (Eisikovits 2014)

These were precisely the major concerns of ETA victims during the 1980s, and the Spanish criminal justice system has lived up to their expectations, but for other victims, the situation is not satisfactory. This view suits Spain really well (Tremlett 2006,

22 “In 1976, as part of an unwritten agreement known as the pacto del olvido, or pact of forgetting, the Fascists agreed to cede power on the condition that no one would be held to account for crimes committed during the Civil War and the dictatorship". See Harvey 2019.

${ }^{23}$ One of the most comprehensive and balanced studies of Spanish transition is Paloma Aguilar (2011). She mentions risk-aversion as a key factor. 
Encarnación 2008). What if there is a tacit or explicit agreement not to dwell on the past? And what if it were a deal to ensure impunity? Was the amnesty law 46/1977 abused in its Article 2 so that crimes and offences committed by state officials - civil servants generally, military, judiciary, police, secret agents - could go unpunished and their perpetrators continue safely in office? Should future generations be bound by such self-immunity? No convincing answers have been found for these questions, but the UN Human Rights Committee requested Spain in 2009, and again in 2014, to abolish its Amnesty Law (Ley 46/1977). Article 2 of the Amnesty Law is the basis for the Supreme Court's refusal to authorise, under Spanish law, any inquiry into the crimes against humanity that may have been committed during the Franco coup d'état and the dictatorship. ${ }^{24}$ The Spanish highest court denies the relevance of international instruments of Human Rights. The first legal ground formulated by the court is that "the right to know historical truth is no business of criminal procedure". This statement goes against pillars (1) and (3) of the four modern pillars of international legal system: (1) international human rights law; (2) international humanitarian law; (3) international criminal law; and (4) international refugee law.

In the Spanish Transition, only the future shape of constitutional society, was really debated, and the transition period itself, which is considered to have concluded with the failed coup d'état of 23 February 1981 and the victory of the Socialist Party in the October 1982 general elections, was a lost opportunity to think collectively about the failures, injustices and repressions of the past, many of them carried on to the transition period. The general understanding was that discussing the past would be hazardous whereas discussing the future would wash out the past and provide automatic catharsis. The Monarchy secured transition, but also its inherent injustice. The judiciary, intelligence and the police forces, the military, state administration, all were secured from the dictatorship and not only left intact, but allowed to continue and often promoted. There was not even any process of "lustration", as there had been under Franco, who removed all civil servants suspect of sympathising with the Republic, from judges to teachers. Some Central European countries did go through a process of lustration after Communism. In Spain, only representative political institutions, i.e. elected local and national assemblies and their governments, or the new organs such as the Constitutional Court were staffed by persons not directly linked to the Franco regime during the Transición.

The attempts at TJ in Spain have come too late and have been circumscribed to a policy of "historical memory". The law on historical memory came late, long after transition was completed, it was a form of post-transitional justice. ${ }^{25}$ In the few instances where truth seeking through judicial means has been explored they have been curtailed, as the Garzón case illustrates (Bengoetxea 2011).

\footnotetext{
${ }^{24}$ In its judgment clearing Garzón of the charges of "prevaricación" concerning his initial investigation of crimes against humanity perpetrated during Francoism, STS of 27 February 2012, the Tribunal Supremo considers that Spanish transition was exemplary.

${ }^{25}$ The Law on Historic Memory (52/2007) tries to recover a democratic memory to claim the narrative of the victims of Francoism and to value the $2^{\text {nd }}$ Republic and the 1931 Constitution thus facing up to the hegemonic political narrative of "transition" that has legitimised the current constitutional system; see Escudero 2013, p. 338.
} 
The majority of Spanish legal and political culture does not interpret the treatment of ETA violence and its Human Rights violations as having anything to do with TJ, but rather as a mere application of the criminal justice system to ordinary crime. The issue of victims and policies and laws designed to recognise and repair (part of) the damage caused to victims has also come rather late (Ley 32/1999, Ley 29/2011), and whereas many victim's organisations do carry out a discourse that resonates of TJ, this discourse sometimes serves as call to enforce retribution and punishment under the criminal justice system. In a sense TJ is discarded in favour of traditional criminal justice.

The competence over all aspects or matters related to Justice and the Criminal Justice system are reserved to the central State (in a federal system, this would be equivalent to the Federation, or the National, federal, level). The Spanish parliament has thus adopted key laws concerning Amnesty, victims, terrorism, the Criminal Code and Criminal Procedure, execution of penalties and the prosecution service, the penitentiary law, and such matters. There is little, if any, scope left at the regional or federated level even if any of these powers are devolved. The only devolution in the criminal justice system so far has been the transfer of the management of prisons to the Catalan government. As regards victims of political violence, Spain has adopted three major legislative instruments:

1. The Amnesty Act of 1977, clearing all possible crimes committed before that year including those committed by the State or its organs. This meant full impunity for state crimes. Victims of such crimes would be left unattended.

2. The Act on Historical Memory 52/2007 of 26 December recognises and expands rights and adopts measures in favour of those who suffered persecution or violence during the Civil War and the dictatorship.

3. The Act 29/2011 on the Recognition and Comprehensive Protection of Victims of Terrorism (amending and updating Act 32/1999 of 8 October).

These laws make up a specific system for the protection of victims that defines the conflict as one of terrorism, clears possible state crime, and recognises, in practice, only one category of victim of terrorism. Periodization becomes crucial, since the Amnesty law was adopted one year before the Spanish Constitution, which seems to mark a full stop and new period. Anything that happened before the Constitution (1978) is historical. Whatever took place, under the aegis of the state, within the constitutional regime could not possibly be in breach of human rights and would not be ascribed to the State. Landa (2018; see also Landa and Garro 2019) considers the Spanish system for the protection of victims of violence has two major traits: asymmetry and hierarchy. It is asymmetric because there are different standards of protection - attention, reparation, recognition, homage - depending on the victim/perpetrator relation. These different standards are conditional, not on the type of breach or crime, but rather on the actor or perpetrator. The type of human rights violation may be the same, but the nature of the victim changes. In my analysis, this is the other side of the so-called criminal law of the enemy (Jakobs), the memory of "our" victims, victimized by our enemy. Victims of ETA terrorism have maximum protection. Victims of other forms of terrorism especially those linked to paramilitary groups often find obstacles in their 
recognition as victims of terrorism, and thus reparation is also blocked. The Lasa and Zabala judicial saga mentioned above is a good illustration. ${ }^{26}$

The European Court of Human Rights ruled on 18 July 2019 that this differentiation in the status of victim, and this corollary denial of reparation does not breach the right to the presumption of innocence recognised in the Convention (Article 6, 2). ${ }^{27}$ Victims of the Historical Memory Act have a lower degree of reparation and recognition. Finally, victims of police abuses seeking recognition and reparation have sometimes seen the State questioning the perpetrations altogether, for cases occurring after 1978. This asymmetry and hierarchy of victims is built-in into the Spanish criminal justice system and supported by the major political parties in Spain.

The picture would not be complete if France was not at least briefly mentioned. France was a sort of sanctuary for ETA activists during the Franco dictatorship, and although Basque national movements developed also there, and even armed wings of ETA like iparretarrak were set up, ETA refrained from striking in France. Its first, and last, mortal victim related to the French state happened in a road control shooting near Paris in 2010, and it may have been fortuitous. France has always seen ETA as a Spanish problem, but then police cooperation was enhanced, the European Arrest Warrant came into effect and some recent episodes concerning its application not only to ETA prisoners but also to political activists has shown that France is actively involved in the cooperation with Spanish intelligence in their general policing of ETA and its "environment". France follows a similar criminal justice system approach regarding ETA, but the involvement of its prosecution and police Departments in facilitating the decommissioning of ETA's arsenal on 8 April 2017 and to replacing ETA prisoners closer to the Pays Basque clearly point to a more pragmatic, nuanced, approach than the Spanish State has had.

\subsection{Transitional Justice in the Basque Country}

The Basque Country lived the transición in a particularly intense way. Paloma Aguilar points out that during transition, almost all actors were aware of the need to repair damage to the victims of the first years of "Francoism", with the result that later

\footnotetext{
${ }^{26}$ See the Order of the Spanish Constitutional Court, TC Order 5656-2015, of 27 February 2017 denying protection, and see dissenting opinion of Justice Asua (Justice Dal Re concurring).

${ }_{27}$ The two cases (Larrañaga Arando and Others $v$ Spain and Martinez Agirre and Others $v$ Spain) concern the relatives of six victims killed by the paramilitary groups BVE, ANE, GAE and GAL. They received reparation according to the Victims of Terrorism Act of 1999, but this Act was amended in the 2011 Victims of Terrorism Act, which included an exception to reparation based on a 1983 Council of Europe Convention on Compensation of Victims of Violent Crimes if the victims had any relationship with an organization that engages in acts of violence. The Spanish government denied reparation on the grounds that the victims were members of ETA, and yet there had been no judicial sentence declaring their membership of any terrorist organization. The Court has admitted that administrative authorities can look into other criteria in order to determine whether the victims were members of ETA. Police or media reports are valid sources of information to establish that link for the purpose of reparation by an administrative authority. The presumption of innocence would only be affected in criminal proceedings of a judicial nature. In my view, the case should not have been brought under the presumption of innocence but rather the right to property of Protocol 1 of the Convention, in relation to the prohibition of discrimination recognized in Article 14.
} 
repressive episodes, of the $60 \mathrm{~s}$ and $70 \mathrm{~s}$, lower in numbers but very significant, were somewhat neglected.

In the Basque Country, however, violence had a higher visibility, given that repression was more severe [than in the rest of Spain] precisely during the second half of the dictatorship, after ETA began carrying out terrorist attacks. This explains why the absence of retroactive justice was criticized more in the Basque Country than elsewhere. Indeed, reservations regarding the nature of the transition process as a whole are much greater in the Basque Country, particularly among the Nationalist electorate (...) continuity in terms of personnel in repressive institutions helps to explain the lower level of legitimacy of democracy among the nationalist Basque electorate. (Aguilar 2001, 117)

The criminal justice system is a competence of the Spanish Parliament - criminal law generally - and Government - criminal policy and penitentiary policy and administration - and the judiciary is a centralised power of the State. Attorneys or public prosecutors are only relatively autonomous, functionally and organically, since there is ultimately a functional and political link with the Spanish executive. As regards the normative strategy adopted in the Basque Country (Basque Autonomous Community and Foral Community of Navarre), this has been adopted within the framework of their limited powers, and always subject to the norms adopted by Spain. Therefore the asymmetry and hierarchy of victims mentioned above, the status of the victim depending on the status of the perpetrator, still remains in large.

Basque Parliament adopted Act 4/2008 of 19 June 2008 on victims of terrorism and Basque Government adopted the decree 107/2012 of 12 June to repair victims of human rights abuses between 1978 and 1999. This was followed by Act 12/2016 of 28 July of the Basque Parliament, amended by Act 5/2019 of 4 April, on recognition and reparation of those victims. In Navarre, Foral Act 16/2015 of 15 April, to recognise and repair victims of politically motivated acts of violence by groups of the extreme right or public servants. Both Acts, Basque and Navarrese, cover the final phase of the Franco dictatorship (1960-1978), in line with the Spanish Act on Historical Memory. This Navarrese Act (Ley Foral 16/2015) was declared unconstitutional by the Spanish Constitutional Court (judgment 85/2018 of 19 July 2018) by a very thin majority alleging it invaded exclusive State powers to judicially declare that an individual was the victim of abuse by State servants. In a similar vein, Basque Act 12/2016 of 28 July to recognise and repair victims of human rights abuses (1960-78) was re-drafted in order to take that constitutional ruling into account, and the State announced it would not dispute the constitutionality of the Act and withdrew its action. However, MPs of political grouping Ciudadanos and Popular Party of Spain both lodged new actions for constitutional review. Navarre adopted a law on historical memory and the Basque Autonomous Parliament was presented with a citizens' legislative initiative with a Bill on the subject and the Basque Government has tabled a draft for a legislative proposal on historical memory in July 2019, as mentioned above.

Behind such legislative framing of victims (and perpetrators), there are different views as to what the Basque conflict, giving rise to political violence, is really about. This generates different explanations or theories about the conflict, from those who deny the existence of any conflict behind "terrorism" to those who dilute the ethical burden of violence into the political conflict, as though it was a war. The framing of the 
narrative about the conflict then shapes the categorisation of the victims and perpetrators, and the preconceptions about the type of data that need to be collected. The data about the conflict diverge along two interrelated axes: i) numbers of victims and ii) labelling of "victims" and time-periods. The debates around the numbers of victims and casualties depend on how the conflict is narrated, and on the labels that are used. The "war" on numbers relates to whether one includes victims of police abuse. This affects the categorisation of the data on victims.

The most accurate approximations to the numbers have been carried out by Basque Government reports. The Basque Government produced a report on breaches of human rights in the years 1960 to 2013 based on research by Carmena, Landa, Mugica and Uriarte (2013). It gives the following numbers: victims killed by ETA were 837; victims wounded by ETA are 2,600; victims killed by State-related terrorism (paramilitaries) were 73; victims wounded by State-related terrorism are 426; victims killed by the action of State agents were 94 and victims wounded by the action of State agents are 746. This report does not include cases of torture. Another Basque Government research report, on torture and degrading treatment between the years 1960 and 2014, documented 4,000 cases of alleged torture by State agents. It was carried out by IVAC and the team of Etxeberria, Martin and Pego (2016) and contains Conclusions and Recommendations. These numbers and reports are yet to be complemented for other types of victims: those 511 local counsellors threatened by ETA (between 1999 and 2011) and needing bodyguards (Intxaurbe Vitorica et al. 2019), those extorted or subjected to preventive ransom money. The data are yet to be published in official reports.

There have been a number of memorial initiatives that are generating and keeping archives and media, legal and historical data as regards the different episodes or expressions of political violence that have taken place in the Basque Country. The ceasefire declared by ETA in 2011, the decommissioning of its arsenal in April 2017 and its final dissolution in May 2018 are triggering a "competition" on data and on figures concerning the victims of the conflict. The narratives constructed around such figures and phenomena tend to diverge. Historians are drawn into the debate, and institutions are financing research and memorial projects to construct versions of the truth about the past. The two main victim-recognition initiatives are the Centro Memorial de Víctimas del Terrorismo, incorporated by Spanish Parliament Act 29/2011; and the Gogora Institute, incorporated by Act 4/2014 of the Basque Parliament. ${ }^{28}$ The dynamics

\footnotetext{
28 The Memorial Centre closely follows the Spanish political system's view of the Basque conflict as reduced to ETA terrorism and its defeat by the democratic system and the Spanish security forces. The Gogora Institute goes back one hundred years and covers other forms of political violence, where ETA is the most important, but not the only, perpetrator of the recent memory period. Both are aiming to collect data and reconstruct facts as accurately as possible in order to preserve memory. But, the lexicon used by each of the Memorials is notably different. The Memorial Centre uses a securitarian framing - "terrorist threat", "terrorists", "terrorism", "the real causes of the victims", "victims of terrorism" - together with the language of morality - "ethical values embodied by the victims of terrorism", victims of terrorism as an "ethical reference for our democratic system", creating an "account that avoids moral or political equidistances, ambiguities" or value neutrality", reflect with "absolute clarity who suffered the damage and who caused $i^{\prime \prime}$. The Memorial Centre clearly states the moral superiority of the victims of terrorism, making no attempt to explain the political motivations behind the acts of "terrorism". There is no historical periodization. Victims of terrorism have moral truth on their side and the role of the historian and the
} 
behind Memory institutions, memorials and research projects launched and financed by the Spanish Government and those under the aegis of the Basque Autonomous Institutions all deal with the conflict in a certain way. But they frame it into different, not necessarily opposing, historical and normative narratives. These are not the only organisations dealing with Memory of the violent conflict. There are several others, and some of them have set up databases, repositories and listings. ${ }^{29}$ Ownership over the discourse about the conflict is no monopoly of any them, but the official organisations like the two mentioned above, are particularly important in that are the result of the will of the legislature, the political representatives of the whole of Spain and of the Basque Autonomous Community.

The scope for legislative action - hard law - of the Basque institutions in the sphere justice, and also of TJ is thus very limited, if not void. It is limited to social welfare, to soft measures, and to the handling of the Basque police. In spite of those shortcomings, during the last years, since 2007, the Basque Parliament and Government have managed to finalise reports on victims ${ }^{30}$ on both sides of the conflict and adopt measures, decrees, seeking some form of relief. A Committee has been set up in the Parliament in order to elaborate a Report on Peace, but the Basque branch of the Spanish Popular Party, crucial for any agreement at a larger, Spanish scale, has decided not to participate and the Spanish Socialist Party branch of the Basque Country has followed suit.

On the other hand, there is some scope for soft measures of TJ for the Basque autonomous institutions - Government and Parliament and its federated institutions, provincial parliaments and governments and its municipalities. All these institutions can use their instruments and agencies to adopt certain recommendations, plans, petitions, host high-level meetings, Peace Conferences and similar activities but they have a very limited scope for adopting specific laws, so long as these laws do not bear upon the criminal justice system, a competence of the state. When there is agreement between all institutions involved it becomes possible to adopt small-scale measures of TJ in the area of penitentiary policy and facilitate the transition from retributive to restorative justice. An example of such experiences under the previous PSOE government is the so-called restorative encounters or "Nanclares way", where ETA prisoners and their victims engaged in face-to-face conversations (see generally Universidad de Deusto 2012, and Bilbao 2013). The PP Government discontinued these innovative and interesting initiatives, and the subsequent PSOE Governments have not officially resumed them.

\footnotetext{
Memorial is to clarify that truth. This moral superiority of the victims of terrorism turns the unfairness and injustice of their victimhood to a higher "political" status, which leaves no scope for ambiguity, where victims cannot possibly be perpetrators. The references above are taken from their respective websites.

29 The following are the major sites containing data on victims (of ETA): Fundación Víctimas del Terrorismo, Archivo Online sobre la violencia terrorista en Euskadi, Centro Documental de la web de la Fundación Fernando Buesa, Mapa del Terror del Colectivo de Víctimas del Terrorismo (Covite), Youtube de la Asociación Víctimas del Terrorismo.

${ }^{30}$ Whereas the Report and the 4/2008 Law on the Victims of Terrorism entitled Ley de Reconocimiento y Reparación a las víctimas del Terrorismo was relatively easy to get through, the 2011 Report on the "other victims" was amply discussed and its long title reveals the compromises behind it: Report on Victims of Human Rights breaches and unjust sufferings produced in a context of politically motivated violence.
} 
TJ is not only about the institutional side of governance, top-down. The civil society bottom-up component is essential, and this is no longer the ambit of constitutional distribution of competences or decision-making by legislatures, courts and executives. There is a broad scope for social initiatives by social movements, citizens, NGOs, and for auzolan (community cooperation in Basque). Indeed, it is mostly these bodies and groups that are bringing about a wave of civil society-based TJ, often with the support of the different Basque institutions.

Also, when analysing the issue of conflict, Human Rights and transitional justice in the Basque Country and in Spain, it is pressing to keep explanatory and normative discourses in mind, their mutual interactions notwithstanding. As Basque academics and researchers we are not and have never been neutral analysts of conflict, and our personal normative stances have conditioned and influenced our own explanations of the conflicts that have struck Basque society. ${ }^{31}$ The same applies to Spanish scholars generally.

TJ in the Basque Country does not refer to regime change. Rather it refers to a field and a scenario after the dissolution of ETA where measures are agreed and adopted as regards the past - truth seeking, historic memory - as regards the present - recognition of the harm caused to victims and to society generally, full respect of human rights and procedural guarantees by the State and all its organs - and as regards the future - the facilitation of progressive and gradual measures towards ETA prisoners' reintegration, non-repetition and reconciliation. The horizon of such TJ would be a new scenario where the conflict and the human rights abuses committed in response to the conflict are part of collective memory and serve as a foundation of the social contract for peace and respect for all. Narratives about the past will be contrasted in the near future.

This transitional justice should also reopen the examination of human rights abuses during the dictatorship and even before that, during the Civil war. The Supreme Court seems to have closed the doors of formal, institutional justice for this purpose, and other forms of "justice" will have to be explored to satisfy the need for truth, justice and reparation. Criminal law options not being really available, it might be worth exploring other, non-legal options, starting from reporting past violations, recognition of victims, and measures to ensure that truth, i.e. knowledge of past events is sufficiently disseminated, giving victims the chance to tell their stories. It could even seek formulae of compensation or reparation. Some possible examples are Truth and Reconciliation Commissions, special Truth-seeking Forum, ad-hoc civil society and academic conferences with participation of international observers.

It is too early to say whether any of these might materialise. What we already have witnessed on the official, institutional side, are the memorial centres mentioned above, the Basque Government Plan for Peace and "Living Together" (now Plan for Human Rights and Living Together which contain many proposals for action and for social encounter, including plans for Education - schools and universities), or the Gipuzkoa Provincial Government Plan for Human Rights, Recovery of Historical Memory and

\footnotetext{
${ }^{31}$ As regards my own stance, I have always opposed violence, whatever its source, aim or origin, before and after Spanish transition. Also I defend so-called equidistance theory: equal refusal of human rights violations coming from ETA and its sympathisers and from the Spanish State and its paramilitary.
} 
Spreading "Living Together", 32 (2012-2015, later transformed by the provincial coalition governments). On the civil society side, we have seen many encounters of the "permanent social forum", or even restorative encounters as the aforementioned Nanclares way, or the the Glencree experience where some victims of all sides in the Basque armed conflict met and discussed in Northern Ireland, trying to avoid slogans and labels like "terrorism" or "political violence", and the large number of local initiatives for restorative encounters as in Rentería, Tolosa... Some of the most interesting expressions of civil society initiatives can be found in the French Pays Basque. Artisans de la paix is worth mentioning because their initiatives managed to reach an agreement between the main actors, ETA activists, French State officials, key international personalities, local politicians, local NGOs and victims to facilitate the surrendering of the arms (2017) and the final dissolution of ETA (2018).

These steps have not so far led to the adoption of new measures to facilitate second chances: brokering special measures for the release of ETA prisoners with no blood crimes and no direct involvement in such crimes (what we could call "political prisoners"), ${ }^{33}$ and special measures for the ultimate solution for "blood" prisoners at the final stages of transition. This should extend to measures aiming at the recognition of harm caused to victims and to society generally.

The processes of dialogue and negotiations regarding the Basque violent conflict - the end of terrorism - have ranged from clandestine peace talks (such as, in the past, those of Argel, Switzerland, Loiola, Oslo) to International Peace Conferences (Aiete Declaration, Donostia-San Sebastian, 17 October 2011), through international mediators, verification and support committees, open deliberations with institutions and civil society. The Brussels Declaration of March 2010 made by Nobel Price and other prestigious facilitators or mediators, the Gernika Agreement of September 2010 calling on ETA to declare a final ceasefire, were important predecessors to the historic Aiete Declaration which brought the final ceasefire three days later. The Social Forum of May 2013 and the Latin American Conference of leaders on 17 October 2013 confirmed the Aiete Declaration on its second anniversary. Decommissioning and final dissolution were the sequels to the Aiete Peace Conference, but with a particular trait: the adoption of unilateralism as a strategy. The Aiete Declaration called on Spain (and France) to adopt measures to facilitate the end of ETA. There was an expectation of bilateralism, that such an initiative by ETA should be followed by some encouraging, even if timid measures, adopted by the State. But time passed and those expectations, and the social pressure re-enacting them, were frustrated. The response given by Civil Society and the NGOs, including political movements in its ideological orbit pushing for TJ has been to put pressure on ETA to continue along the path it took with the final ceasefire, and to facilitate the decommissioning by acting as go-betweens with ETA combatants to receive their arsenal and the French authorities to hand the arsenal to

\footnotetext{
32 "Living together" is the euphemism for reconciliation in the Basque Country both in Spanish, "convivencia", and in Basque, "bizikidetza". For some reason, reconciliation is avoided as excessively ambitious or pretentious, even quasi-religious.

33 The term "political prisoners" is not only theoretically complex, but also in practice it becomes a disputed term with serious outcomes. The Basque Parliament (May 2013) passed a motion to declare that there are no political prisoners in Spain, meaning prisoners of "conscience" stricto sensu. The term has again come up in the context of the leaders of the Catalan sovereignty movement.
} 
them, with the presence of Basque society, since all these moves were made public and carried out in public (April 2017). The next logical step for the Artisans and civil society was to convene a team of world re-known personalities to witness the declaration on its dissolution by ETA and make it known to the wider public in Cambo, Pays Basque (4 May 2018).

These unilateral steps were not negotiated with Spanish authorities, who insist that their only approach is the strict application of the criminal law, but they were symbolically carried out before Basque Civil Society. In its final Declaration of dissolution ETA published a communiqué (3 May 2018) where it lamented all the suffering it had inflicted on Basque and Spanish society, and it specifically asked for pardon to the victims and relatives of victims who had no personal involvement in the "struggle". This apology of sorts was also a unilateral move, but, again, suffered from the activist combatant symbol of "the enemy".

\section{Part Four. Twists in Basque Transitional Justice}

The narrative of the conflict twists from the violence of ETA - inflicted directly on victims and also on all those who felt threatened simply by confronting it - to the violence carried out by State organs and paramilitaries in the fight against ETA and against the MLNV. ${ }^{34}$ State violence has gone beyond those usual targets to include and criminalise its socio-political "environment" (el entorno del entorno).

Some examples of the twists immediately following the ceasefire are the following: the adoption of preliminary measures to interrogate the mayor of Gernika, Mr Gorroño, who had awarded a special peace price to two prominent politicians engaged in peace talks: Jesus Egiguren and Arnaldo Otegi, who later served sentence for cooperation with a terrorist organisation (EFE 2013); in the eve of the second anniversary of the ETA communiqué declaring a final ceasefire in October 2011, eighteen representatives of Herrira, the NGO that supports the rights of ETA prisoners, were arrested; the trial against members of SEGI, the youth organisation that followed the work of the banned Jarrai; the opening of the trial in case 35/02 before the Audiencia Nacional where several ex-leaders of the nationalist left were prosecuted for membership of ETA and over 100 popular taverns (Herriko Tabernak) could be confiscated for engaging in illegal activities in support of ETA. We have mentioned the case of trial 11/13 before the Audiencia Nacional against the so-called prison front of lawyers, decided in September 2019. One of the most outrageous abuses, in my opinion, is the case of the Altsasu Young persons sentenced by the Audiencia Nacional (7 March 2019) to up to 13 years imprisonment for their injuries (one fractured ankle and some bruises) to two Civil Guards in a pub fight at five in the morning on 15 October 2016 (Davies 2018). As journalist Pascale Davies explains in this article, "the decision to transfer the case from Pamplona to the Audiencia Nacional was made by Carmen Lamela - the same judge who jailed Catalonia's separatist leaders for sedition and rebellion last year. The prosecution alleged terrorist intent because some of the accused had been involved with a social movement that advocates the removal of state security forces from Navarre - a position also held by ETA". The eight youth were sentenced to up to 13 years for assault, aggravated by hatred and ideological discrimination against the Civil

${ }^{34}$ On the ideology behind the MLNV see the insightful work by Iñigo Bullain (2010). 
Guard officers and their girlfriends. On appeal, in judgment of 9 October 2019, the Tribunal Supremo brought down the sentence to 9 years imprisonment. The very Audiencia Nacional ruled out that the events had any connection to terrorism, and yet that was the very ground to try them before that court in Madrid, and not before the Pamplona court.

Such twists historically created a spiral of violence: repression-reaction-repressionreaction. Happily, ETA's unilateral decision to end the spiral means new strategies will replace terror and violence, but the strategy of repression by the Spanish criminal justice system has not ceased. These trials and arrests, together with other moves like the refusal to investigate allegations of torture, for which Spain has been declared in breach of the European Convention of Human Rights on more than one occasion, or the so-called Parot doctrine retroactively imposing more restrictive punitive penitentiary measures regarding the length of the sentence served, also under the censure of the European Court of Human Rights (Judgment Ines del Río, 21 October 2013); or the design of specific crimes in the Criminal Code for the Basque conflict like street violence or kale borroka - now mark, in my view, a deterioration of human rights standards in the fight against terrorism and a threat to the democratic and rule of law quality of the Spanish criminal justice system. This is so to such an extent that restoring the democratic credibility and standards of the criminal justice system in Spain could, paradoxically, be regarded as the most important measure of TJ: restoring the criminal justice system, in line with democratic principles.

The first principle upon which there should be agreement is the need to limit and keep to the minimum recourse to the criminal law and the criminal justice system when considering not only TJ options, but also, more generally, the treatment of conflict itself. Acts that are not directly related to the commission of crimes and harm against others should not be dealt with from the criminal law, but even for typical criminal processes, distension should always be an option. The principle of Ultima Ratio (Bengoetxea et al. 2013) together with the principles of democracy, legality, and proportionality should inspire the criminal justice system.

There is also a twist from individual to structural responsibility. As was mentioned in Part Two in the discussion of some key issues in TJ, a dilemma haunts the use of criminal law in "transition": Does the unique nature of mass atrocity, wherein numerous people harm others with differing degrees of acquiescence and direction from a large bureaucratic class, really lend itself to the legalistic commitment to individualizing guilt on the basis of direct evidence? Or do the distinct features of such crimes require relaxing our standards of individual responsibility so as to implicate the entire state structure that made the atrocities possible? An application of this dilemma to the Basque context would lead to consider responsibility of the state apparatus behind the paramilitary group GAL, or in the cases of allegations of torture against $X$, where the structurally protected torture practices make it difficult to identify the perpetrator. The same difficulty of identifying the individual actor has been no obstacle however for the prosecution in support of the criminal theory that treats all the social movements around the Basque nationalist left as "part of ETA". There is no need to identify individual criminal acts of violence since belonging, showing signs of support, sometimes seems enough to be considered a member of a terrorist group. 
The second suggestion is to create the possibility for all Society to engage in an ideal rational discourse on memory: what happened and how and why it happened. There are several initiatives and organisations on all sides to work on memory, some of them projecting back to the Civil War atrocities, but it would be desirable for them to twist and talk to each other and contrast their experiences. Memory and truths, how the conflict is told, narratives and stories are especially important. Also, one should not forget the special power of the media in constructing narratives. Pluralistic and participatory mass media and opinion-creating circles should contribute to an ideal discourse situation where narratives are twisted and tested.

Reparation of harm and damage caused to victims is one logical consequence of the knowledge and recognition of the past. Recognition is the first step of reparation, but obviously forms of expression of regret on having caused the harm, as long as they are sincere, are to be welcome. Sincere apologies are unlikely to be the result of statutorypenitentiary requirements. Truth, recognition and reparation are initial steps towards justice for the victims. But trying to ensure that victims participate actively in the processes of memory and of reparation, and also obviously in the definition of the policies and measures of Transitional Justice, and in the political debates altogether, is also important. For this purposes, three ensuing principles would be desirable:

(i) not to make distinctions between victims, i.e. victims of one group or one camp v victims of other camps. Distinguishing victims depending on the actors who victimised them is a categorical mistake, which implies accepting the categories and labels attached on the victims by the perpetrators. There should be no difference between victims. It is regrettable that so much division has come out in the victims' world in Spain, not only as regards violence related to the Basque Country but also as regards other attacks and violations, as in the case of the Al Quaida bombings in the Atocha train station in Madrid, March 2004;

(ii) not denying the status of victim because the person has been a perpetrator, a risk often detected in torture justifying discourse, or in the lowering of procedural standards to "terrorists"; and

(iii) ensuring victim participation should not extend to politically affording them a special voice or weighted votes or veto powers. Regardless of their ethical status as victims, they should be treated like all other citizens in political deliberation. But special efforts should be directed at having their voices heard. On the other hand, it is worth asking about the dimension of time in victimhood: how long is a victim still a victim? The status of victimhood can fuse with an identity of the "victim".

Prisoners who have been condemned for harm caused to others - whatever their camp - and prisoners who have been condemned for trying to organise political activity should be clearly distinguished cases. For prisoners who have been involved with violence and human rights violations, it would be desirable to adopt an overall strategy agreed by most political parties in the Basque Country. The policy of distancing prisoners to far away prisons should be discontinued and prisoners brought to prisons closer to their home, and those prisoners who have irreversible diseases could and should be released in application of the existing penitentiary legislation 
(Ríos Martín 2017, 2019). No more is required than to apply the existing penitentiary legislation. Reintegration in society is the aim of any civil criminal justice system.

A political agreement on ETA prisoners has not taken place yet, even amongst Basque national parties. It could deal with issues like recognition of harm caused, regret, repent, asking for sincere apologies, analysis of the actual crimes perpetrated, length of prison term already served, and time left, need to make sure society is satisfied with a general solution, and also comparison with the prison terms served by representatives of the Spanish state condemned for violations of Human Rights. The conditions under which the sentence has been served, e.g. prison regimes, how far from the family the prison is located (the policy of dispersal and distancing, sometimes over $800 \mathrm{~km}$ was started in the mid-80s and is generally considered unfair and an additional punishment on prisoner and relatives who often have to drive more than $1,500 \mathrm{~km}$, spend three days and over 1,000 euros per visit). The general discussion on the principle of Ultima Ratio should extend to a discussion of prisons and incarcerations.

Just as there are interactions between the interpretative and normative approaches to TJ, there are also connections between individual and collective perspectives. Feelings of pardon, revenge, guilt, remorse, pain, hatred, despise, mistrust, indifference are individually felt but collectively reconstructed and the social and political meaning given to them goes beyond the individual experience. And this again poses a challenge to the traditional criminal procedure individuating guilt and responsibility, as opposed to collective responsibilities. It also affects the narratives of conflict, since an individual criminal sentence hides the social dimension of crime and conflict.

The interest of society normally lies in facilitating the transition from a destructive relationship to a constructive one, and this is something individuals concerned will experience in different ways. A victors' justice that insists on the strict application of the law for some perpetrators, "terrorists" and "enemies" while excusing or minimizing the seriousness of other violations of Human Rights, by organs of the state is a real obstacle to such transition. It distorts memory and combines over-punity for foes with impunity for friends. It is an unjustified discrimination. Likewise, pretending that a unilateral ceasefire, important as it is, should be sufficient in order to ensure a smooth and rapid "transition" is a serious mistake, the same mistake that was made in the Spanish Transition. It avoids memory and recognition of harm and re-victimizes not only direct victims but society at large. The harm done by the perpetrators was the result of a moral choice to kill, no matter how strong the ideological reasons to build up sufficient hatred to kill someone. Basque society would expect at least some sincere account of the past. TJ will explore the terrain between those two pragmatic contradictions (Martín Beristain, quoted in Duplá 2013, 4-7, at p. 6), ${ }^{35}$ always under the guidance of respect for Human Rights, as defined and understood by international conventions.

35 "[R]ecognition of the many faces of suffering, of human rights violations and liability of the State need not imply equalizing all processes of victimization nor any form of symmetry of harms nor that all situations are comparable. It only means to recognize the importance of the issues so as to create a framework of legitimation for the reconstruction of social fabric (...). [A]ny narrative on truth and memory would therefore need to be inclusive". (Our translation). 
The general discussion of the field and its application to the Basque case show, in my view, that both strategies -traditional and transitional justice are needed - and that they need not contradict, but rather complement each other. A scenario of justice and rule of law after violence and conflict of ETA is necessary given the immense harm ETA has caused to Basque and Spanish societies. But it is also a scenario of justice and rule of law and fundamental rights after abuses made by the State in the fight against ETA, which has extended abuses to Basque society generally. Perhaps the tension could be put this way, addressing the justice issues regarding political violence and crimes will require a combination of tools from the field of TJ like truth seeking, access to justice outside the formal institutional criminal law, and forms of reparation. It will also require that the state and its officials apply their TJ with full respect for human rights.

\section{References}

Aduriz, I., 2019a. ETA y Catalunya: las prioridades en la estrategia de la renovada dirección del PP. Eldiario.es [online], 2 August. Available from: https://www.eldiario.es/politica/ETA-Catalunya-prioridades-estrategiaCasado 0 927057467.html [Accessed 21 January 2020].

Aduriz, I., 2019b. Víctimas de ETA responden a la nueva estrategia del PP: “Utilizan el dolor ajeno con intereses partidistas". Eldiario.es [online], 6 August. Available from: https://www.eldiario.es/politica/Victimas-ETA-PP-sufrimientoDejen 0 928107674.html [Accessed 21 January 2020].

Aguilar, P., 2001. Justice, Politics and Memory in the Spanish Transition. In: A. Barahona de Brito, C. Gonzalez Enriquez and P. Aguilar, eds., The Politics of Memory: Transitional Justice in Democratizing Societies [online]. Oxford University Press, 92-118. Available from: https://doi.org/10.1093/0199240906.003.0004 [Accessed 21 January 2020].

Bell, C., 2009. Transitional Justice, Interdisciplinarity and the State of the "Field" or "Non-Field". International Journal of Transitional Justice [online], 3(1), 5-27. Available from: https://doi.org/10.1093/ijti/ijn044 [Accessed 21 January 2020].

Bengoetxea, J., 2011. Seven Theses on Spanish Justice to understand the Prosecution of Judge Garzón. Oñati Socio-Legal Series [online], 1(9). Available from: http://opo.iisj.net/index.php/osls/article/view/48 [Accessed 21 January 2020].

Bengoetxea, J., Jung, H., and Nuotio, K., eds., 2013. Ultima Ratio, a principle at risk. European perspectives. Oñati Socio-Legal Series [online], 3(1). Available from: http://opo.iisj.net/index.php/osls/issue/view/20/showToc [Accessed 21 January 2020].

Bilbao, G., 2013. Una difícil pero imprescindible recuperación social tras la violencia. Galde, no 1, pp. 10-11.

Bullain, I., 2010. Revolucionarismo Patriótico. El Movimiento de Liberación Nacional Vasco (MLNV): Origen, ideología, estrategia y organización. Madrid: Tecnos.

Closa, C., 2011. Dealing with the Past: Memory and European Integration [online]. Jean Monnet Working Paper 01/11. Available from: https://doi.org/10.2139/ssrn.1972355 [Accessed 21 January 2020]. 
Corradetti, C., 2013. Editor's introduction. Philosophy of Transitional Justice: Conceptual Problems and Political Perspectives. In: C. Corradetti et al., eds., Special Issue: Philosophy of Transitional Justice. Philosophy of Transitional Justice, Forthcoming [online]. MultiRights Research Paper no 13-2; University of Oslo Faculty of Law Research Paper no 2013-08. Available from: https://ssrn.com/abstract=2213708 [Accessed 21 January 2020].

Davies, P., 2018. Basque bar fight trial tests 10 years of fragile peace in the region. The Guardian [online], 14 April. Available from:

https://www.theguardian.com/world/2018/apr/14/basque-country-bar-fight-highcourt-ruling-terror-related [Accessed 21 January 2020].

Duplá, A., 2013. Carlos Beristain. Entrevista. Galde, no 2 (Spring), pp. 4-7.

EFE, 2013. Un juez imputa al alcalde de Gernika por premiar a Otegi. El País [online], 13 July. Available from: https://elpais.com/ccaa/2013/07/13/paisvasco/1373732432 154531.html [Accessed 21 January 2020].

Eisikovits, N., 2014. Transitional Justice. The Stanford Encyclopaedia of Philosophy [online]. Available from: https://plato.stanford.edu/entries/justice-transitional/ [Accessed 21 January 2020]. (Originally published in 2009).

Encarnación, O.G., 2008. Reconciliation after Democratization: Coping with the Past in Spain. Political Science Quarterly [online], 123(3). Available from: https://doi.org/10.1002/j.1538-165X.2008.tb00630.x [Accessed 21 January 2020].

Escudero, R., 2013. Jaque a la Transición: análisis del proceso de recuperación de la memoria histórica. Anuario de Filosofía del Derecho [online], 29, pp. 319-340. Available from: https://dialnet.unirioja.es/descarga/articulo/4550640.pdf [Accessed 21 January 2020]

Harvey, G., 2019. Spain's Most Celebrated Writer Believes the Fascist Past is Still Present. New York Times, 1 August.

Hayner, P., 2002. Unspeakable Truths: Facing the Challenges of Truth Commissions [online]. New York: Routledge. Available from: https://doi.org/10.4324/9780203903452 [Accessed 21 January 2020].

Honneth, A., 2004. Recognition and Justice. Outline of a Plural Theory of Justice. Acta Sociologica [online], 47(4), 351-364. Available from: https://doi.org/10.1177/0001699304048668 [Accessed 21 January 2020].

Klare, K., 1998. Legal Culture and Transformative Constitutionalism. South African Journal on Human Rights [online], 14(1), 146-188. Available from: https://doi.org/10.1080/02587203.1998.11834974 [Accessed 21 January 2020].

Koskenniemi, M., 2005. From Apology to Utopia: The Structure of International Legal Argument [online]. $2^{\text {nd }}$ ed. Cambridge University Press. Available from: https://doi.org/10.1017/CBO9780511493713 [Accessed 21 January 2020].

Landa, J., 2018. Políticas de víctimas de la violencia política en España y el País Vasco: una reflexión a la luz del holocausto. Revista General de Derecho Penal, 29. 
Landa, J.M., dir., and Garro, E., coord., 2019. Euskadi después de la violencia/Euskadi indarkeriaren ondoren. Bilbao: Servicio Editorial UPV/EHU.

Macklem, P., 2005. Restitution \& Memory in International Human Rights Law. European Journal of International Law [online], 16(1), 1-23. Available from: https://doi.org/10.1093/ejil/chi101 [Accessed 21 January 2020].

Minow, M., 1998. Between Vengeance and Forgiveness. Boston: Beacon Press.

Ríos Martín, J.C., 2017. La gestión de la ejecución de la pena de prisión en relación con personas presas por terrorismo. INDRET [online], 4. Available from: http://www.indret.com/pdf/1333.pdf [Accessed 21 January 2020].

Ríos Martín, J.C., 2019. Medias y fines de la política penitenciaria para presos de ETA. In: A. Rivera and E. Mateo, eds., Víctimas y política penitenciaria: Claves, experiencias y retos de futuro. Madrid: Catarata.

Rome Statute of The International Criminal Court 1998 [online]. Available from: https://legal.un.org/icc/statute/99 corr/cstatute.htm [Accessed 21 January 2020].

Teitel, R., 2000. Transitional Justice. Oxford / New York: Oxford University Press.

Tremlett, G., 2006. Ghosts of Spain: Travels Through Spain and its Silent Past. New York: Walker \& Company.

Umana, C., 2017. Impunity: in the search of a socio-legal concept. Elucidations from a State Crime case study [online]. PhD thesis. University of Ottawa, Social Science Faculty, Doctorate in Criminology / University of the Basque Country, Doctorate in Sociology of Law. Available from: https://ruor.uottawa.ca/bitstream/10393/36916/3/Umana Camilo 2017 thesis.pdf [Accessed 21 January 2020].

Universidad de Deusto, ed., 2012. Justicia para la convivencia: los puentes de Deusto. Encuentro "Justicia retributiva y restaurativa: su articulación en los delitos de terrorismo". Junio 2012. Bilbao: Publicaciones de la Universidad de Deusto.

Legal sources

Ley 12/2016, de 28 de julio, de reconocimiento y reparación de víctimas de vulneraciones de derechos humanos en el contexto de la violencia de motivación política en la Comunidad Autónoma del País Vasco entre 1978 y 1999. Boletín Oficial del País Vasco [online], no 151. 10 August. Available from: http://noticias.juridicas.com/base datos/CCAA/580656-1-12-2016-de-28-jul-capais-vasco-de-reconocimiento-y-reparacion-de-victimas.html [Accessed 21 January 2020].

Ley 29/2011, de 22 de septiembre, de Reconocimiento y Protección Integral a las Víctimas del Terrorismo. Boletín Oficial del Estado [online], nº 229. 23 September. Available from: https://www.boe.es/eli/es/1/2011/09/22/29 [Accessed 21 January 2020].

Ley 32/1999, de 8 de octubre, de Solidaridad con las víctimas del terrorismo. Boletín Oficial del Estado [online], nº 242. 9 October. Available from: https://www.boe.es/eli/es/1/1999/10/08/32 [Accessed 21 January 2020]. 
Ley 4/2008, de 19 de junio, de Reconocimiento y Reparación a las Víctimas del Terrorismo Boletín Oficial del País Vasco [online], no 124 . 1 July. Available from: http://www.euskadi.eus/bopv2/datos/2008/07/0804014a.pdf [Accessed 21 January 2020].

Ley 46/1977, de 15 de octubre, de Amnistía. Boletín Oficial del Estado [online], nº 248. 17 October. Available from: https://www.boe.es/buscar/doc.php?id=BOE-A-197724937 [Accessed 21 January 2020].

Ley 5/2019, de 4 de abril, de modificación de la Ley 12/2016, de 28 de julio, de reconocimiento y reparación de víctimas de vulneraciones de derechos humanos en el contexto de la violencia de motivación política en la Comunidad Autónoma del País Vasco entre 1978 y 1999. Boletín Oficial del País Vasco [online], no 74.16 April. Available from: http://noticias.juridicas.com/base datos/CCAA/642696-1-52019-de-4-abr-ca-pais-vasco-modificacion-1-12-2016-reconocimiento-y.html [Accessed 21 January 2020].

Ley 52/2007, de 26 de diciembre, por la que se reconocen y amplían derechos y se establecen medidas en favor de quienes padecieron persecución o violencia durante la guerra civil y la dictadura. Boletín Oficial del Estado [online], nº 310. 27 December. Available from: https://www.boe.es/buscar/doc.php?id=BOE-A-2007$\underline{22296}$ [Accessed 21 January 2020].

Ley Foral 16/2015, de 10 de abril, de reconocimiento y reparación de las víctimas por actos de motivación política provocados por grupos de extrema derecha o funcionarios públicos. Boletín Oficial de Navarra [online], nº 71. 15 April. Available from: http://www.lexnavarra.navarra.es/detalle.asp? $\mathrm{r}=35672$ [Accessed 21 January 2020].

Case Law

STS 101/2012. Sala Segunda, de lo Penal. 27 de Febrero de 2012. Ponente: Andrés Martínez Arrieta [online]. Available from: https://supremo.vlex.es/vid/prevaricacion-crimenes-franquismo-injusticia356948146 [Accessed 21 January 2020].

Supreme Court, Criminal Chamber. Judgment № 459/2019 of 14 October 2019. Special Proceedings № 20907/2017. Rapporteur: The Honourable Manuel Marchena Gómez [online]. Available from: http://www.poderjudicial.es/stfls/TRIBUNAL\%20SUPREMO/NOTAS\%20DE\%20 PRENSA/20191216\%20STS,\%20Sala\%202,\%2014-10-2019\%20\%20Sentencia\%20proc\%C3\%A9s\%20INGL\%C3\%89S.pdf [Accessed 21 January 2020].

\section{Reports}

Carmena, M., et al., 2013. Informe-base de vulneraciones de derechos humanos en el caso vasco (1960-2013) [online]. Secretaría General de Paz y Convivencia, Gobierno Vasco. Available from: http://www.ogasun.ejgv.euskadi.eus/r51catpub/es/k75aWebPublicacionesWar/k75aObtenerPublicacionDigitalServlet?R01 
$\underline{\text { HNoPortal }=\text { true } \& N \quad \text { LIBR }=051379 \& N \quad \text { EDIC }=0001 \& C \text { IDIOM }=e s \& F O R M A T O=. p}$ df [Accessed 21 January 2020].

Etxeberria, F., Martín Beristain, C., and Pego, L., 2016. Proyecto de investigación de la tortura en el País Vasco (1960-2013) [online]. Secretaría General para la Paz y la Convivencia, Gobierno Vasco. 27 June. Available from:

https://www.euskadi.eus/contenidos/informacion/documentos paz convivencia/ es def/adjuntos/Memoria\%20Proyecto\%20tortura\%202016.pdf [Accessed 21 January 2020].

Informe sobre las víctimas de vulneraciones de Derechos Humanos y sufrimientos injustos producidos en un contexto de violencia de motivación política, 2011 [online]. Secretaría General para la Paz y la Convivencia, Gobierno Vasco. Available from: https://www.jusap.ejgv.euskadi.eus/r47dhlinea2/es/contenidos/informacion/ddhh victimas vulneraciones/es ddhh/adju ntos/Informe V\%C3\%ADctimas-de-violencia-de-motivaci\%C3\%B3npol\%C3\%ADtica\%20.pdf [Accessed 21 January 2020].

Intxaurbe Vitorica, J.R., González Hidalgo, E., and Urrutia Asua, G., 2019. Informe sobre la injusticia padecida por concejalas y concejales que sufrieron violencia de persecución (1991-2011) [online]. Secretaría General de Derechos Humanos, Convivencia y Cooperación, Gobierno Vasco/Instituto de Derechos Humanos Pedro Arrupe, Universidad de Deusto. 12 July. Available from:

https://bideoak2.euskadi.eus/2019/07/12/news 55825/Informe persecucioi n con cejales cas.pdf [Accessed 21 January 2020].

Landa Gorostiza, J.M., 2009. Bases para la puesta en marcha de una Comisión de la Verdad en Euskadi. Gobierno Vasco [online]. Dirección de Derechos Humanos, Departamento de Justicia, Empleo y Seguridad Social, Gobierno Vasco. 31 March. Available from: https://docplayer.es/61517072-Bases-para-la-puesta-en-marcha-de-unacomision-de-la-verdad-en-euskadi.html [Accessed 21 January 2020].

Report of the Special Rapporteur on the promotion of truth, justice, reparation and guarantees of non-recurrence, Pablo de Greiff (A/HRC/30/42) [online]. United Nations Human Rights Council, 7 September 2015. Available from: https://www.ohchr.org/Documents/Issues/Truth/A-HRC-30-42.pdf [Accessed 21 January 2020].

The rule of law and transitional justice in conflict and post-conflict societies: Report of the Secretary-General (S/2004/616) [online]. New York: United Nations SecretaryGeneral, 23 August 2004. Available from: https://digitallibrary.un.org/record/527647?!n=es [Accessed 21 January 2020]. 